Published in International journal of business and emerging markets, 2016, vol. 8, no. 3, pp. 340-358, which should be cited to refer to this work

\title{
Southern MNCs in Switzerland and regional productivity spillovers in services/construction industry
}

\section{Lamia Ben Hamida* and Racha Khairallah}

University of Applied Sciences Western Switzerland // HES-SO, La Haute école de gestion Arc, Espace de l'Europe 21 CH-2000 Neuchâtel, Switzerland

Email: Lamia.benhamida@he-arc.ch

Email: racha.khairallah@gmail.com

*Corresponding author

\begin{abstract}
As more developing and transition market firms (southern MNCs) are engaged in outward FDI in European advanced economies, a fundamentally important question has to be addressed: whether this investment leads to positive productivity effects for host economies. Our paper addresses this issue by examining whether there are indicators of regional spillovers from the entry and the presence of southern MNCs in the service/construction industry. We suggest that: 1) regional spillovers from southern MNCs are co-determined by local and foreign characteristics, namely, FDI motivation and technological capacity of the local host country firms; 2) possible interaction effects between local technological capacity and FDI motivation would also influence the size and the extent of regional spillovers from southern MNCs. Using firms-level data from Switzerland, we found that knowledge-exploiting FDI (KE FDI) and knowledge-seeking FDI (KS FDI) have different amounts of spillovers. In addition, human capital development in local firms appears to be essential in gaining large regional spillovers. This allows for positive regional spillovers for high technology firms when southern MNCs are assigned KE mandates and for low technology firms when southern MNCs invest in KS FDI.
\end{abstract}

Keywords: Southern MNCs; productivity spillovers; regional effect; foreign and local characteristics; FDI motivation; service industry.

Reference to this paper should be made as follows: Ben Hamida, L. and Khairallah, R. (2016) 'Southern MNCs in Switzerland and regional productivity spillovers in services/construction industry', Int. J. Business and Emerging Markets, Vol. 8, No. 3, pp.340-358.

Biographical notes: Lamia Ben Hamida is a Professor of Economics at la Haute école de gestion Arc of the University of Applied Sciences Western Switzerland, HES-SO. Her research interests focus on: multinational corporations and foreign direct investment (FDI), innovation activity and technology transfer, FDI and export spillovers, learning processes and technological change, and FDI policies.

Racha Khairallah is a PhD student in Economics at the University of Sfax. Her doctoral thesis focuses on multinational corporations and spillover effects in Europe.

This paper is a revised and expanded version of a paper entitled 'Southern MNCs in Europe and regional productivity spillovers in services/construction industry: evidence from Switzerland' presented at the Reading-UNCTAD International Business Conference, Reading, 13-14 June 2015. 


\section{Introduction}

Outward foreign direct investment (FDI) expansion from developing and transition economies (called hereafter southern economies ${ }^{1}$ ) reached $39 \%$ in 2013 in terms of global outflows (UNCTAD, 2014). In addition, relating to the UNCTAD global ranking, southern economies are continuously ranked among the top-20 investors. These economies have witnessed an unprecedented rapid expansion of their outward FDI in developed countries, particularly, in Europe (UNCTAD, 2011). For example, "Overseas investment by BRICS countries is mainly in search of markets in developed countries or in the context of regional value chains. Over 40 percent of their outward FDI stock is in developed countries, of which 34 percent is in the European Union" [UNCTAD, (2013), p.5].

The international and rapid expansion of southern multinational corporations (MNCs) is viewed with a mixture of hope and fear from European host countries (Gorgoni et al., 2012), because southern MNCs have demonstrated economic success and inventive capacity by building new knowledge and practices (Duport, 2014). This new knowledge and practices could thereafter be disseminated in the host economy (Ben Hamida and Khairallah, 2014).

In this context, we need to investigate whether southern MNCs investment may benefit local economies in Europe. We concentrate on regional spillover effects from southern MNCs FDI activities and test these effects in the context of the Swiss service/construction industry ${ }^{2}$. To the best of our knowledge, very little attention has been given to spillovers from southern MNCs to developed host economies. The contribution of this study lies in demonstrating how local and foreign characteristics jointly determine spillover productivity outcomes in Swiss regions. We argue that, firstly, the effects of regional spillovers are significantly influenced by the type of FDI motivation of southern MNCs, and secondly, possible interactions between FDI motivations and local technological capacities may have different spillover effects on local firms productivity.

We posit that on the one hand, southern MNCs FDI motives impact regional spillovers the same way as conventional explanations. On the other hand, these effects are co-determined by the interaction between FDI motives and local technological capacities. High and low technology firms do not enjoy the same benefit from the presence of southern MNCs in their region. We hypothesise that:

a spillover benefits from the presence of KE-southern MNCs in the region leads to higher productivity improvement in low technology firms

b regional spillovers from KS FDI provide higher productivity improvement in high technology firms.

Our contribution lies in linking local inter-firm differences in productivity spillover effects to FDI motivations of southern MNCs and testing regional spillover effects in the service/construction industry. ${ }^{3}$

Following this introduction, the next section discusses theoretical and empirical frameworks underlying our hypotheses. In Section 3, we introduce the model we use to test spillovers from southern MNCs. Section 4 analyses Swiss data. Section 5 discusses regression results and Section 6 concludes the paper. 


\section{Theoretical framework}

An increasing number of studies have analysed spillovers from northern or advanced economies to southern/northern economies, whilst, to the best of our knowledge, little attention has been paid by scholars to study these effects from southern MNCs to northern economies, particularly, concerning Europe. Our study focuses on the resultant effect of southern MNC investment in terms of regional spillovers in Switzerland. We use a theoretical framework linking local technological heterogeneity to knowledge mandates of southern MNCs affiliates. Sub-section 2.1 highlights the need to assess spillovers at the regional level. Sub-sections 2.2 and 2.3 discuss theoretical and empirical frameworks underlying our hypotheses.

\subsection{On the role of regional effect}

When spillover effects are measured for local firms in all regions (i.e. at a national level), the regional benefits might not be observed if they are too small to offset the overall negative effect across all regions ${ }^{4}$ (Aitken and Harrison, 1999). Learning is expected to be highly localised (Yildizoglu and Jonard, 1999) and spillovers are geographically bound.

Technological interaction among firms is deeply rooted in regional space (Menghinello et al., 2010). Spillovers tend to be captured, firstly, by local firms located in the same region as foreign affiliates and may gradually spread to other, more distant ones (Aitken and Harrison, 1999). Firms in the same location/region tend to follow the same technological trajectory wherein technological disparities are expected to be smaller, since MNCs are more likely to establish affiliates in more competitive regions (Dunning, 1992). In addition, knowledge is transmitted more efficiently by local proximity and its transmission costs are assumed to increase with distance (Audretsch, 1998). Local firms in the same region observe and imitate foreign technology more efficiently than others. The channels of technological diffusion are reinforced at regional level (Crespo et al., 2008).

Despite these regional arguments, existing results for regional spillovers are rather mixed for country analyses. For example, Aitken and Harrison (1999), Driffield (2004), Higón and Vasilakos (2011), Liu and Wei (2006) and Xu and Sheng (2012) found evidence for regional spillovers; whereas, Halpern and Muraközy (2005), Sjöholm (1999), Kokko and Kravtsova (2012) and Lin and Kwan (2014) failed to confirm that regional dimension matters. This heterogeneity on regional spillover findings could be a result of misspecification of these effects which are conditional on a number of factors.

We argue that local and foreign firms characteristics, as well as, their interactions jointly determine regional productivity outcomes. In the following sub-sections we put forward the role of FDI motivations and local technological characteristics in assessing regional spillovers from southern MNCs.

\subsection{On the role of foreign characteristics}

MNCs make foreign investment that either assist them in exploiting existing technological capabilities or enable them to build new competences, new knowledge sources and augment their asset base. Foreign units which rely on the centralised knowledge pool of the MNC and focus on activities which are adaptive in nature, have 
been referred to as knowledge exploiting (KE) or home base exploiting units (Kuemmerle, 1997; Cantwell and Piscitello, 2005). In contrast, units motivated by the objective to source available knowledge in foreign markets and create new technologies and capabilities have been referred to as knowledge seeking (KS) or home base augmenting units.

We posit that different types of FDI motives have markedly different sizes of spillovers. Foreign firms motivated by exploiting their existing knowledge abroad, actively contribute to the transfer of new technologies to the host country and then to the expansion of local spillover benefits. Such units usually attempt to adapt the technology created by the parent company or other units to meet needs and preferences in the host market. Therefore, they are less interested in identifying and using knowledge and technologies from the location in which they operate. However, MNCs' activities as a means of acquiring host country's knowledge enjoy the benefit of absorbing technology spillovers from local firms. The knowledge-seeking view suggests that firms may expand abroad in search of capabilities complementary to those available in their home markets (Ben Hamida and Piscitello, 2009, 2010; Cantwell, 1989). Southern MNCs compared to local firms in advanced economies are assumed to not possess strong tangible assets and often pursue strategic asset-seeking FDI in these markets. Awate et al. (2015) compared the R\&D internationalisation of emerging market MNCs to that of advanced economy multinationals and found that they have different processes in which the strategy of the former is to catch up with industry leaders while the latter create competence and exploit activities. Makino et al. (2002) found that firms from newly industrialised economies tend to invest in developed countries when they have strategic asset-seeking and market-seeking motivations, moreover in least developed countries when they have labour-seeking motivations. The motivation to carry out strategic asset seeking FDI decreases or even disappears when local firms in the host country lag behind emerging market MNCs in technology (Wang et al., 2014) and when home country knowledge base is at a lower level (Elia and Santangelo, 2012).

Zhan (1995), Buckley et al. (2007) and Milelli and Hay (2008) pointed to a market-seeking objective before an asset-seeking one, as the main driver in the arrival of emerging market MNCs in Europe, in particular Chinese and Indian firms. However, Deng (2007) found that Chinese MNCs are broadly motivated by strategic resources and capability seeking activities in order to offset competitive disadvantages and to leverage their unique ownership advantages (Rui and Yip, 2008).

To sum up, southern MNCs seem to be primarily motivated by market seeking FDI in Europe. In this regard, since the literature considers the access to the market as knowledge exploiting motivation, southern foreign affiliates in this case are assigned knowledge exploiting mandates. In addition, the literature has shown that southern MNCs are broadly motivated by seeking knowledge in European host economies. They accumulate competences and offset competitive disadvantages in given host economies to leverage ownership advantages (Milelli and Hay, 2008). This catching-up process with advanced economy MNCs allows them to move as fast as possible from imitation to innovation by obtaining the appropriate lessons through repeated practices (Mathews, 2006). In doing so, southern MNCs would be able to develop new competences and technologies which could thereafter be a valuable source of knowledge for local European firms.

A great number of studies have analysed spillovers for the host economy according to FDI motivations, but without distinguishing between southern MNCs and advanced 
economy firms and concerning mainly manufacturing industry. For example, Driffield and Love (2006) found that spillover effects are positive when FDI is motivated by the desire to exploit some competitive advantages possessed by the UK over the period 1984-1995 and negative when FDI is motivated by the desire to access the technology of UK manufacturing firms. This result seems to be confirmed by the work of Girma (2003), using more recent UK manufacturing data between 1989 and 1999. Both studies have used R\&D intensity (RDI) as a proxy to identify KE and KS affiliates. That is if RDI of the home country is less than RDI of the host country, foreign firms are considered knowledge seekers; otherwise they are knowledge exploiters. Moreover, Driffield and Love (2007) showed, using datasets of FDI flows into the UK from 30 countries over the period 1987-1997, that technology-sourcing FDI led to no spillovers. UK firms gain substantial spillover benefits only from FDI motivated by a strong technology-based ownership advantage.

A similar differentiation between asset-seeking (technology sourcing) and asset-exploiting (technology exploiting) motivations was used by Marin and Sasidharan (2010) who found, however, that firms oriented to technologically creative activities have significant and positive effects in India, while firms oriented mostly to technologically exploitative activities generate negative effects in some circumstances. They distinguish between competence creating (CC) and competence exploiting (CE) firms using R\&D and export intensities. They define competence creating firms as those investing heavily in R\&D and having a high export intensity, otherwise firms are considered as competence exploiters. These findings seem to be confirmed by Ha and Giroud (2015) for Korea. In a similar vein, Cantwell and Smeets (2013) claimed that the productivity effects of technology seeking inward FDI may indeed be expected to be positive, and are at least as likely to occur as those of technology exploiting FDI. Their finding seems to support their claim at industry level data for 13 OECD countries from US MNCs.

In this context, our paper recognises that the nature of knowledge transferred from southern MNCs to the local economy would differ according to FDI motivations of these firms and consequently provide differences in learning and regional spillover results. This points to the following hypothesis:

H1 Regional spillovers from southern MNCs in Switzerland differ based on the motivations of the southern MNCs.

\subsection{On the role of local characteristics}

We believe that successful transfer of knowledge requires local receiving units to have a certain degree of technological capacity to be able to successfully absorb foreign knowledge. In other words, low technological capacity may thwart critical learning processes at the firm which in turn would not benefit from new technologies (Cohen and Levinthal, 1989; Michel and Narula, 2009; Piscitello and Rabbiosi, 2004). Technologies have a certain firm-specific aspect to them and then need to be decoded in order to be efficiently used by local firms, raising their productivity. In addition, the wealth of local human capital contributes significantly to successfully internalising foreign technologies and enhances the knowledge base of local firms (Borensztein et al., 1998; Meyer and Sinani, 2005).

Foreign affiliates are not only considered as purely technological containers of strategic assets, transferred by the parent company and other MNCs' units, but they are 
supposed to adopt a more technologically active behaviour, particularly, when they have been assigned the role of knowledge seekers. Knowledge exploiting FDI units usually attempt to adapt the technology created by other MNCs' units to local preferences, whereas knowledge seeking FDI units tend to source new knowledge and augment their asset base.

Local firms are required to adapt their learning process to benefit from spillovers of foreign affiliates, which in turn depends on their technological level. Foreign firms from advanced economies which are active in knowledge exploiting activities contribute to augmenting the knowledge base of the host country by bringing the best new ideas and processes from the rest of the corporation. In this case local firms may need to have sufficient technological capacity to be able to recognise valuable new knowledge, integrate it into the firm and use it productively. Knowledge seeking FDI units may also contribute to the local knowledge base by developing new technologies and products based on the local knowledge reservoir. These competences and technologies could be a valuable source of knowledge for the host economy. Local firms in this case may also need to have sufficient technological capacities to benefit from spillovers.

Southern MNCs compared to advanced economy firms are assumed not to have ownership advantages since their home country knowledge base is smaller than that of developed European economies 5 . In this respect, we argue that local firms with high technological capacity do not have interest in looking at southern MNCs' knowledge. They would not abandon their existing pattern of innovation and imitate the technological knowledge of foreign competitors (Cantwell, 1999; Silverberg and Verspagen, 1994). They would rather work harder and gain spillovers through competition effects. However, low technology firms, which are at a similar knowledge level and/or lag far behind southern MNCs, try to find a way to acquire southern MNCs' new knowledge to be able to successfully compete with them in their region. Therefore, we expect that spillover benefits from the presence of KE-southern MNCs in the region with market seeking objectives leads to higher productivity improvement in low technology firms than high technology ones.

Conversely southern MNCs motivated by accumulating intangible assets need to absorb local knowledge by acquiring local firms and/or sourcing knowledge spillovers. In doing so, these firms are highly likely to become more efficient and develop new competences which could afterwards spill over to local firms. As stated by $\mathrm{Ha}$ and Giroud $(2015$, p.3), "CC subsidiaries maintain frequent and close contacts with local business partners, allowing a conduit for reciprocal knowledge exchange between the MNE and host-country firms, facilitating subsidiary learning from local entities and enhancing knowledge and technology spillovers from subsidiaries to local entities".

Accordingly, high technology firms which are in a position to compete fiercely with more efficient southern MNCs in their region are expected to gain higher benefits than low technology ones. Low technology firms may need to upgrade their human capital to be able to decode and successfully absorb foreign knowledge, since knowledge in the service industry is much more embedded in human capital (Ben Hamida, 2011).

We believe then that interactions between MNCs' investment motives and local technological capacities would be considered important in understanding how local firms benefit from the presence of southern MNCs in their region. These interactions might influence the size and the extent of the potential regional spillover benefit that local firms might enjoy.

These arguments are described in Table 7 and point to the following hypotheses: 
H2 Interactions between different technological capacities of local firms and the motivations of southern MNCs to invest in Switzerland provides differences in how local firms benefit from regional spillovers.

$\mathrm{H} 2 \mathrm{a}$ Spillover benefits from the presence of KE-southern MNCs in the region leads to higher productivity improvement in low technology firms than high technology ones.

$\mathrm{H} 2 \mathrm{~b}$ Spillover benefits from the presence of KS-southern MNCs in the region leads to higher productivity improvement in high technology firms than low technology ones.

\section{The model}

We model the effect of regional spillover from southern MNCs within the context of a production function, in which the natural $\log$ value added of the $i^{\text {th }}$ local firm is determined as follows;

$$
\begin{aligned}
\operatorname{LnY}_{i, j}= & \alpha_{0}+\alpha_{1} \operatorname{LnL}_{i, j}+\alpha_{2} \operatorname{LnK}_{i, j}+\alpha_{3} F P_{j, r}+\alpha_{4} F P_{j, R-r}+\alpha_{5} H C_{i, j} \\
& +\alpha_{6} F P_{j, r} * H C_{i, j}+\alpha_{7} F P_{j, R-r} * H C_{i, j}+\alpha_{8} \operatorname{Camp}_{i, j} \\
& +\alpha_{9} \text { Industry }_{j}+\alpha_{10} \text { Region }_{r}+\varepsilon_{i, j, r}
\end{aligned}
$$

where the subscripts $i$ and $j$ denote firm and industry, and $\alpha_{0}$ to $\alpha_{10}$ are the parameters to

\begin{tabular}{|c|c|}
\hline Variable & Definition \\
\hline $\operatorname{Ln} Y_{i, j}$ & $\begin{array}{l}\text { The log in value added in a firm measured by the difference between total sales } \\
\text { and intermediate consumption, calculated for } 2010 \text {. }\end{array}$ \\
\hline $\operatorname{Ln} K_{i, j}$ & $\begin{array}{l}\text { The log in physical capital, measured by gross capital income (the difference } \\
\text { between firm's total sales and costs in terms of intermediate consumption and } \\
\text { labour, calculated for 2010). }\end{array}$ \\
\hline$L n L_{i, j}$ & The log in total number of employees in a firm, calculated for 2010 . \\
\hline$F P_{j}$ & $\begin{array}{l}\text { The share of total sales in an industry } j \text { accounted for by foreign firms, } \\
\text { calculated for } 2010 \text {. }\end{array}$ \\
\hline$F P_{j, r}$ & $\begin{array}{l}\text { The share of total sales in an industry } j \text { within the region } r \text { accounted for by } \\
\text { foreign firms, } r=1 \ldots R \text {, with } R=7 \text {. }\end{array}$ \\
\hline$F P_{j, R-r}$ & $\begin{array}{l}\text { The share of total sales in an industry } j \text { outside the region } r \text { accounted for by } \\
\text { foreign firms. }\end{array}$ \\
\hline$H C_{i, j}$ & The labour cost of the firm, calculated for 2010 (in 100,000 s of CHF). \\
\hline $\operatorname{Comp}_{i, j}$ & $\begin{array}{l}\text { The price markup at firm level measured by the difference between firm's total } \\
\text { sales and costs over total sales, calculated for } 2010 \text {. }\end{array}$ \\
\hline $\operatorname{Gap}_{i, j}$ & $\begin{array}{l}\text { The ratio of the average labour productivity of foreign-owned firms to local firms' } \\
\text { own labour productivity, calculated for } 2010 \text {. }\end{array}$ \\
\hline K-motiv & $\begin{array}{l}\text { The average of external innovation-relevant knowledge sources, calculated for } \\
2010 \text { (five-point intensity scale). }\end{array}$ \\
\hline
\end{tabular}
be estimated. Table 1 describes the variables and their measurements.

Table 1 Variable definitions

Note: ${ }^{a}$ External sources could be rival firms, customers, suppliers, universities, and patent disclosures. 
$Y$ denotes value added at firm level, $K$ its physical capital measured by the gross capital income, $L$ its employment measured by the number of employees, and $H C$ the level of its human capital proxied by the labour cost calculated for 2010, this measurement allows to test whether local firms succeed in absorbing foreign knowledge when they invest in human capital (namely, training and/or recruitment). The coefficients of these variables are expected to be positive and significant.

The inclusion of industry dummies, Industry, in equation (1) controls for the industryspecific productivity differences; it corrects for the omission of unobservable variables that might undermine the relationship between spillover variables and the productivity of local firms.

Following regional spillover studies, we include in equation (1) regional foreign share, $F P_{j, r}$, and that from outside the region, $F P_{j, R-r}$, in order to test for regional aspect. Regional foreign share is measured as the share of sales of foreign firms in the industry within the region, which is used as a proxy of regional spillovers. In addition, we employ two interaction terms $F P_{j, r} * H C_{i, j}$ and $F P_{j, R-r} * H C_{i, j}$ between the level of local human capital and the shares of foreign presence in the region and from outside the region, respectively. We expect that increases in skills will augment the productivity of local firms since this affects their knowledge capital and enhances their learning capacity (Griliches, 1998; Narula and Marin, 2003). The regions considered here are; the Lemanic region, Mittelland space, North West Switzerland, Zurich, Western Switzerland, Central Switzerland, and Ticino ${ }^{6}$. We also include regional dummies, Region, to account for agglomeration effects that may result in an upward bias of a region-specific spillover coefficient, since some foreign firms could be attracted to regions which benefit from agglomeration economies (Aitken and Harrison, 1999). ${ }^{7}$

We use price mark-up to capture the effect of competition which could be induced by the entry and presence of southern MNCs. ${ }^{8}$ Following Narula and Marin (2003) and Chung (2001), we measure the firm's price mark-up by the difference between firm's sales and costs over total sales. When mark-up is high, i.e. a value near 1, competition is low and when mark-up is low, i.e. a value near 0 , competition is high ${ }^{9}$. A negative estimated coefficient attracted by the mark-up is consistent with the expectation that decreased mark-up (increased competition) is followed by an increase in productivity.

In order to test our Hypothesis 1, we divide the full sample of local firms into two sub-samples characterised by the type of FDI motivation and we estimate equation (1) separately for local firms with knowledge exploiters and local firms with knowledge seekers. Prior studies have mostly used country R\&D intensity (RDI) to distinguish between FDI motives, given that MNC represents, at least on average, the areas from which it originates. If RDI of home country < RDI of host country; foreign firms are considered knowledge seekers; otherwise they are knowledge exploiters ${ }^{10}$. Recently, Cantwell and Smeets (2013, p.177) recognised that "leaders, and not laggards, are more likely to engage in technology seeking FDI". They suggested that "distinguishing between technology seeking and technology exploiting FDI should preferably go beyond the use of relative R\&D intensities" (p.179).

We agree with this argument and suggest in addition that firms investing in other types of FDI rather than R\&D might use their foreign units to seek local knowledge. Accordingly, we prefer using a measurement 'K-motiv' that clearly points to the importance a southern MNC attaches to local knowledge sources. ${ }^{11}$ This could indicate 
whether they are looking for local knowledge. According to the KOF survey we use in this study, southern MNCs could source local knowledge from their counterparts, their customers, their suppliers, local universities, and patent disclosures. Firms, regardless of the type of their FDI, reveal high importance of local knowledge sources show high values of 'K-motiv' that are larger than the average five-point scale ${ }^{12}$. This demonstrates that foreign firms attach high importance to the knowledge reservoir of the host country and are expected to invest in knowledge seeking and learning. However, low importance (values smaller than or equal to the average five-point scale) indicates that foreign firms are not highly interested in sourcing local knowledge and that their FDI motive would be rather market seeking or knowledge exploiting activities.

In order to test the effect of the interaction between FDI motivations and local technological capacities, we employ technological gaps of local firms, Gap, compared to their foreign counterparts in order to measure existing technological capacities of local firms. Gap is defined as the ratio of the average labour productivity of foreign-owned firms in the relevant two-digit industry to a local firm's own labour productivity, calculated for 2010. Gap is equal to 1 if local firms operate at the same labour productivity as the average-level of its foreign rivals. We distinguish between high and low technological capabilities as follows; values that are smaller than 1 are interpreted as indicators of small productivity gaps (high technological capacity). Values that are higher than or equal to 1 are interpreted as signs of large productivity gaps (low technological capacity). Then we divide the two sub-samples of local firms with knowledge exploiting FDI and with knowledge seeking FDI into four sub-samples characterised by high and low existing technological capacities of local firms.

\section{Data analysis}

Data used in this paper is derived from innovation activity survey (2011) of service/construction firms, with at least five employees, conducted at the Swiss Institute for Business Cycle Research (KOF) ${ }^{13}$. Individual information covers the technological behaviour and productivity performance of local and foreign firms in 2010. It also includes data on the name of the firm's home country we used to determine southern foreign affiliates.

Tables 2, 3, and 4 present a summary of the sample and descriptive statistics of the relative FDI trend of all foreign firms in Switzerland versus southern firms. All these calculations are based on weighted datasets to give a representative picture of the Swiss economy ${ }^{14}$. Table 2 illustrates the importance of FDI for regional development in Switzerland in 2010. It shows some variations in the share of foreign firms across regions in total employment and total sales. When all foreign firms are considered, foreign share was pre-eminent in Zurich in total employment $(22.9 \%)$ and in the Lemanic region in total sales $(61.5 \%)$, while Mitteland space experienced the smallest share in both employment and sales. When focusing on southern MNCs, the regional distribution becomes different where the highest shares are reported by Ticino in total employment and by western Switzerland in total sales, while the smallest share remains in Mitteland space. 
Table 2 FDI participation in services/construction in Switzerland: regional shares of foreign firms (percent)

\begin{tabular}{lcccc}
\hline \multirow{2}{*}{ Region } & $\begin{array}{c}\text { Total } \\
\text { employment }\end{array}$ & $\begin{array}{c}\text { Total } \\
\text { employment }\end{array}$ & Total sales & Total sales \\
\cline { 2 - 5 } & $\begin{array}{c}\text { All foreign } \\
\text { firms }\end{array}$ & $\begin{array}{c}\text { Southern } \\
\text { firms }\end{array}$ & $\begin{array}{c}\text { All foreign } \\
\text { firms }\end{array}$ & $\begin{array}{c}\text { Southern } \\
\text { firms }\end{array}$ \\
\hline Lemanic region $^{\mathrm{a}}$ & 18.047 & 0.799 & 61.573 & 1.004 \\
Mittelland space $^{\mathrm{b}}$ & 4.371 & 0 & 10.977 & 0 \\
North West Switzerland $^{\mathrm{c}}$ & 10.582 & 0.019 & 17.844 & 0.013 \\
Zurich & 22.863 & 0.637 & 27.643 & 0.341 \\
Western Switzerland $^{\mathrm{d}}$ & 7.718 & 1.078 & 17.276 & 3.8 \\
Central Switzerland $^{\mathrm{e}}$ & 14.287 & 0.110 & 57.174 & 0.049 \\
Ticino & 16.585 & 1.373 & 16.817 & 0.328 \\
\hline
\end{tabular}

Notes: ${ }^{a}$ Lemanic region includes the cantons of Vaud, Valais, and Geneva.

${ }^{\mathrm{b}}$ Mittelland space includes the cantons of Bern, Fribourg, Jura, Neuchâtel,

Solothurn.

"North West Switzerland includes the cantons of Aargau, Basel-Stadt,

and Basel-Landschaft.

${ }^{\mathrm{d}}$ Western Switzerland includes the cantons of Appenzell Ausserrhoden, Appenzell

Innerrhoden, Glarus, Graubünden, Schaffhausen, St-Gallen, and Thurgau.

${ }^{\mathrm{e}}$ Central Switzerland includes the cantons of Lucerne, Nidwalden, Obwalden,

Schwyz, Uri, and Zug.

Source: Authors' calculations of data derived from KOF innovation surveys (2011) of services/construction firms

Table 3 Labour productivity and human capital development: difference between foreign and local firms (2010): ratio of the mean of the foreign variable to the mean of the corresponding local variable

\begin{tabular}{|c|c|c|c|c|}
\hline Sector: services/ & $\begin{array}{c}\text { Labour } \\
\text { productivity }\end{array}$ & $\begin{array}{c}\text { Labour } \\
\text { productivity }\end{array}$ & $\begin{array}{l}\text { Labour } \\
\text { quality }^{\mathrm{a}}\end{array}$ & $\begin{array}{l}\text { Labour } \\
\text { quality }^{\mathrm{a}}\end{array}$ \\
\hline construction & $\begin{array}{l}\text { All foreign } \\
\text { firms }\end{array}$ & $\begin{array}{l}\text { Southern } \\
\text { firms }\end{array}$ & $\begin{array}{l}\text { All foreign } \\
\text { firms }\end{array}$ & $\begin{array}{l}\text { Southern } \\
\text { firms }\end{array}$ \\
\hline Services/construction & 1.942 & 1.119 & 1.767 & 1.284 \\
\hline Wholesale trade & 2.186 & 2.027 & 2.594 & 3.562 \\
\hline Retail trade & 1.347 & 0 & 1.530 & 1.462 \\
\hline Hotels/catering & 1.244 & 0.711 & 1.247 & 0.213 \\
\hline Transport & 1.640 & 0.860 & 1.368 & 2.997 \\
\hline Telecommunication & 1.807 & 1.465 & 0.420 & 0.797 \\
\hline Banking/Insurance & 1.757 & 0.618 & 1.155 & 0.701 \\
\hline
\end{tabular}

Note: ${ }^{\text {a }}$ The ratio of professionals - engineers, mangers, and all other professionals in diverse firm's activities - to non-professionals

Source: Authors' calculations of data derived from KOF innovation surveys (2011) of services/construction firms 
Table 4 Importance of external innovation-relevant knowledge sources in Switzerland (five-point intensity scale) $^{\mathrm{a}}$

\begin{tabular}{lcc}
\hline \multirow{2}{*}{ Industry } & $\begin{array}{c}\text { External innovation-relevant } \\
\text { knowledge sources }\end{array}$ & $\begin{array}{c}\text { External innovation-relevant } \\
\text { knowledge sources }\end{array}$ \\
\cline { 2 - 3 } & All foreign firms & Southern firms \\
\hline Services/construction & 2.4 & 2.6 \\
Construction & 2.6 & 4 \\
Wholesale trade & 2.4 & 2.2 \\
Retail trade & 2.1 & 2.3 \\
Hotels/catering & 2 & 2 \\
Transport & 2.2 & 2.2 \\
Telecommunication & 2.5 & 3.2 \\
Banking/insurance & 2.7 & 3 \\
\hline
\end{tabular}

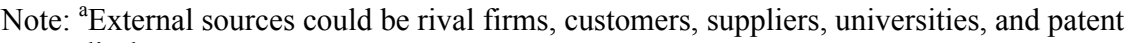
disclosures.

Source: Authors' calculations of data derived from KOF innovation surveys (2011) of services/construction firms

Table 3 reported the relative position of foreign affiliates relative to local firms in terms of labour productivity and labour quality in 2010 . The data for the aggregate suggests that foreign firms hired more professionals, the quality of their labour force was higher. The high level of labour quality was also perceived in southern affiliates relative to similar local firms. Across sectors, the results show that foreign firms hired more professionals in sectors such as wholesale trade, while local firms dominate in sectors such as telecommunication. These results remain relevant for samples with only southern MNCs. The high quality of labour of southern affiliates, at the aggregate level and in some sectors, confirm to some extent that these firms invest in human capital development by recruiting more professionals who could develop new knowledge and technologies. The difference at the aggregate level in terms of productivity denotes the industrial technological gap between local and foreign firms, which is in favour of foreign firms. This result also fits with southern firms showing their relative performance vis-à-vis local firms. Nevertheless, when sectors are considered individually the results using only southern MNCs change considerably and show that in some sectors the gap is small while in others is very high. In wholesale trade and telecommunication for example southern firms perform better than local ones while in transport and banking/insurance local firms perform better.

Table 4 shows the importance of external innovation-relevant knowledge sources in Switzerland as described by foreign firms in 2010. We use this variable to identify knowledge seeking and knowledge exploiting foreign firms. As previously explained, values higher than or equal to 2.5 (the average five-point scale) are interpreted as a sign of KS FDI, otherwise KE FDI. The data for the aggregate indicates that on average, all foreign firms invest in KE FDI while southern MNCs invest in KS FDI. However, across sectors, southern MNCs behave the same way as all foreign firms since the results reported in Table 3 are markedly the same for all foreign affiliates and for southern MNCs. Foreign firms, with strong intensity in southern MNCs, are seeking local knowledge in construction, telecommunication, banking and insurance. They are 
exploiting their knowledge transferred from the home country or seeking new markets in sectors such as; wholesale trade, hotel and catering, and transport.

To sum up, southern MNCs invest in Switzerland in KS FDI in service industries that have achieved competitive technological levels and invest in KE FDI in other sectors ${ }^{15}$. We argue that the diverse FDI motivations of southern MNCs might provide differences in spillover results. We test these effects in the next section at the regional level since learning is highly localised.

\section{Empirical results}

The models are estimated using ordinary least squares. All estimations are robust and all standard errors are corrected for heteroskedasticy.

In regression 5.1 of Table 5, we test the effect of regional spillovers from all southern MNCs on the productivity of local firms in the Swiss service/construction industry, while regressions 5.2-5.6 report regional spillover results according to FDI motivations of southern MNCs and technological capacities of local firms. For all regressions, the value added of local firms in the Swiss service/construction industry significantly increases with their employment, their physical capital and their human capital, except regressions $5.2,5.4,5.6$, and 5.7 for physical capital.

Table 5 Spillover results for services/construction using OLS: the role of FDI motivation and local technological capacity

\begin{tabular}{|c|c|c|c|c|c|c|c|}
\hline & $\begin{array}{c}\text { Full } \\
\text { simple }\end{array}$ & $\begin{array}{c}\text { Knowledge } \\
\text { exploiting } \\
\text { FDI }\end{array}$ & $\begin{array}{c}\text { Knowledge } \\
\text { exploiting } \\
\text { FDI low } \\
\text { GAP }\end{array}$ & $\begin{array}{c}\text { Knowledge } \\
\text { exploiting } \\
\text { FDI high } \\
\text { GAP }\end{array}$ & $\begin{array}{c}\text { Knowledge } \\
\text { seeking } \\
\text { FDI }\end{array}$ & $\begin{array}{c}\text { Knowledge } \\
\text { seeking } \\
\text { FDI low } \\
\text { GAP }\end{array}$ & $\begin{array}{c}\text { Knowledge } \\
\text { seeking } \\
\text { FDI high } \\
\text { GAP }\end{array}$ \\
\hline & 5.1 & 5.2 & 5.3 & 5.4 & 5.5 & 5.6 & 5.7 \\
\hline $\operatorname{LnK}$ & $0.023 * *$ & 0.028 & $0.501 * * *$ & 0.026 & $0.013^{*}$ & 0.007 & 0.025 \\
\hline $\operatorname{LnL}$ & $1.001 * * *$ & $0.982 * * *$ & $0.5 * * *$ & $0.988 * * *$ & $1.011 * * *$ & $0.994 * * *$ & $1.01 * * *$ \\
\hline$H C$ & $0.83 * * *$ & $1.33^{* * *}$ & $0.6^{* * *}$ & $1.5 * * *$ & $0.708 * * *$ & $0.442 * * *$ & $0.96 * * *$ \\
\hline$F P_{j, r}$ & 0.011 & $0.112 * * *$ & $0.043 * *$ & $0.074 * *$ & 0.006 & $0.016^{* *}$ & $0.137 * * *$ \\
\hline$F P_{j, R-r}$ & $-0.063 * * *$ & $-2.85 * * *$ & -0.037 & $-0.608 * * *$ & $-0.063 * *$ & $-0.33 * * *$ & -0.144 \\
\hline$F P_{j, r} * H C$ & $0.043 * *$ & 0.15 & $0.182 * * *$ & 0.143 & $0.036 * *$ & -0.025 & $0.21 * * *$ \\
\hline$F P_{j, R-r} * H C$ & $0.3 * * *$ & 0.47 & -0.155 & $1.183^{* *}$ & $0.356 * * *$ & $0.408 * * *$ & 0.25 \\
\hline Comp & $1.514 * * *$ & $1.603 * * *$ & $-0.304 * *$ & $1.509 * * *$ & $1.85 * * *$ & $1.527 * * *$ & $1.251 * * *$ \\
\hline Industry & Yes & Yes & Yes & Yes & Yes & Yes & Yes \\
\hline Region & Yes & Yes & Yes & Yes & Yes & Yes & Yes \\
\hline $\bar{R}^{2}$ & 0.966 & 0.978 & 0.998 & 0.974 & 0.975 & 0.986 & 0.98 \\
\hline$N$ & 627 & 253 & 82 & 171 & 374 & 200 & 174 \\
\hline
\end{tabular}

Notes: All estimations include industry dummies. All standard errors (shown in parentheses) are corrected for heteroscedasticity. Variables (HC and FP) used for interactions are centred by subtracting the full sample means, so that multicollinearity between the variables and their product is reduced, good estimates of (HC and FP) with accurate size and sign are ensured, and more meaningful interpretations of those estimates are granted (Aiken and West, 1991). $*, * *$, and $* * *$ denote significance at the $10 \%, 5 \%$, and $1 \%$ levels, respectively. 
Table 6 Hypotheses and estimated results

\begin{tabular}{lcc}
\hline \multirow{2}{*}{ Hypotheses } & \multicolumn{2}{c}{ Regressions } \\
\cline { 2 - 3 } & Services/construction & Support(S)/not \\
\hline $\mathrm{H} 1$ & $4.2,4.5$ & $\mathrm{~S}$ \\
$\mathrm{H} 2$ & $4.3,4.4,4.6,4.7$ & $\mathrm{~S}$ \\
$\mathrm{H} 2 \mathrm{a}$ & $4.3,4.4$ & $\mathrm{~S}$ \\
$\mathrm{H} 2 \mathrm{~b}$ & $4.6,4.7$ & $\mathrm{~N}$ \\
\hline
\end{tabular}

Using the full sample of local firms in regression 5.1, the estimated coefficients of $F P_{j, r}$ is positive and insignificant, that of $F P_{j, R-r}$ is negative and significant, while those of $F P_{j, r} * H C_{i, j}$ and $F P_{j, R-r} * H C_{i, j}$ of are positive and significant. This indicates that local firms in the service/construction industry need to upgrade their human capital to reap the benefits from the presence of southern firms in their region and from outside the region.

To test our Hypothesis 1, we divide our full sample of local service/construction firms into two sub-samples of local firms where southern firms are assigned knowledge exploiting and knowledge seeking mandates. Compared to the regression results for the full sample of local firms, regressions 5.2 and 5.5 report different results in which the estimate of becomes positive and highly significant when FDI is defined to be KE type and remains insignificant with $\mathrm{KS} \mathrm{FDI}^{16}$. This finding confirms the result of, among others, Driffield and Love (2006, 2007), Girma (2003), Higón and Vasilakos (2011) and $\mathrm{Xu}$ and Sheng (2012) demonstrates that only FDI with KE motive induce positive knowledge diffusion and regional spillover benefits. The benefit for local firms with KS FDI needs to be co-determined by the level of human capital and seems to be larger from southern firms located outside the region. These findings corroborate our Hypothesis 1, in which regional spillover effects are markedly different when southern MNCs invest in KE FDI or KS FDI.

In regressions 5.3 and 5.4, and regressions 5.6 and 5.7, we split up the two sub-samples of local firms with KE FDI and KS FDI into four sub-samples according to the level of the technological gap between foreign and local firms 'GAP' and we make various tests of regional spillover effects using equation (1). As it is clear from the table, high and low technology firms succeeded in capturing positive and significant regional spillover effects, and low technology firms enjoyed the highest benefit particularly when they increase their human capital. This finding holds true when southern MNCs invest in $\mathrm{KE}$ and when they invest in KS FDI (regression 5.4 and 5.7, respectively). Our finding confirms Hypothesis 2a however, not Hypothesis $2 \mathrm{~b}$.

The estimated coefficient of $F P_{j, R-r}$ remains negative for regressions 5.2-5.7, demonstrating that local firms do not benefit from the presence of southern MNCs outside their region. This negative impact could be interpreted as reverse spillovers (Chen et al., 2012). Productivity response with $F P_{j, R-r}$ becomes positive only when local firms upgrade the level of their human capital, particularly low technology firms with KE FDI and high technology firms with KS FDI.

In addition, we find in regression 5.3 that local firms with high technological capacities and KE FDI enjoy spillovers from competition mechanism since Comp ${ }_{i, j}$ is negative and significant. They also take higher advantage from the presence of KE FDI in their region when they upgrade their human capital. These findings imply that KE FDI contributes to transferring new technologies to the host country and consequently force 
high technology local firms to be more competitive by introducing these technologies and/or by working harder. By strengthening the skills and know-how of their employees (via training and/or recruitment), local firms might find a way to successfully absorb foreign knowledge and reap large benefits from the presence of southern KE FDI. These benefits could be interpreted as an indicator of worker mobility spillovers from southern MNCs if local firms succeeded in upgrading their human capital by attracting local employees who are already trained or have experience in southern MNCs (Ben Hamida, 2007, 2011; Mody, 1989).

These findings confirm our Hypothesis 2 in which interactions between different technological capacities of local firms and the motivations of southern MNCs to invest in Switzerland provides differences in the way local firms benefit from regional spillovers.

\section{Conclusions}

The effect of FDI spillovers from southern MNCs on productivity performance of advanced host countries is a challenging research topic. Southern MNCs are increasingly investing in advanced countries, in particular Europe, moreover this investment is viewed with a mixture of hope and fear from European host countries. There is a need to analyse the contribution of this investment in local development, since many governments pay special attention to spillover benefits when measuring the successful performance of their FDI policies.

This paper argues that spillovers are highly localised and analyses these effects at the regional level of the Swiss service/construction industry. It suggests that

a southern MNCs FDI motives impact regional spillovers

b these effects are co-determined by the interaction between FDI motives and local technological capacities.

On average, our results support conventional theories and demonstrate that only FDI with $\mathrm{KE}$ motive induces positive knowledge diffusion and regional spillover benefits. However, when considering local technological heterogeneity, high- and low technology firms do not use the same trend to benefit from the presence of southern MNCs in their region. Spillover benefits from the presence of KE southern MNCs in the region lead to higher productivity improvements in low technology firms than high technology ones. Conversely, we do not have supportive results of the fact that regional spillovers from KS FDI provide higher productivity improvement in high technology firms than low technology ones.

On the policy front, suggestions with respect to attracting FDI, following such findings, must consider that FDI spillovers from southern MNCs occur in the region and outside the region and largely depend on the existing levels of local technological capacity and FDI motives. Meaning that high- and low technology firms do not follow the same learning process. Their technological behaviour vis-à-vis southern MNCs is co-determined by FDI mandates of foreign affiliates. In addition, local firms regardless of their technological capacities, need to upgrade the level of their human capital to absorb the knowledge of southern MNCs and gain larger effects. Actions should then consider this technological heterogeneity of local firms and support their learning process by helping them to upgrade their level of local human capital. Encouraging collaborations 
between local and foreign southern firms could also be included in a policy package to promote the flow of knowledge between firms and facilitate the assimilation and absorption processes, so as to contribute to successful local learning.

Table 7 Regional spillovers and the interaction between FDI motivation of southern MNCs and local technological capacity

\begin{tabular}{llcc}
\hline & & \multicolumn{2}{c}{ Southern MNCs FDI motivations } \\
\cline { 3 - 4 } & & Knowledge exploiting FDI & Knowledge seeking FDI \\
\hline $\begin{array}{l}\text { Local } \\
\text { technological } \\
\text { levels }\end{array}$ & $\begin{array}{l}\text { High technological } \\
\text { level }\end{array}$ & Small regional spillovers & High regional spillovers \\
& $\begin{array}{l}\text { Low technological } \\
\text { level }\end{array}$ & High regional spillovers & Small regional spillovers \\
\hline
\end{tabular}

\section{References}

Aiken, L and West, S. (1991) Multiple Regression: Testing and Interpreting Interactions, Sage Publications, Newbury Park, CA.

Aitken, B.J. and Harrison, A.E. (1999) 'Do domestic firms benefit from direct foreign investment? Evidence from Venezuela', American Economic Review, Vol. 89, No. 3, pp.605-618.

Audretsch, D.B. (1998) 'Agglomeration and the location of innovative activity', Oxford Review of Economic Policy, Vol. 14, No. 2, pp.18-29.

Awate, S., Larsen, M.M. and Mudambi, R. (2015) 'Accessing vs sourcing knowledge: a comparative study of R\&D internationalization between emerging and advanced economy firms', Journal of International Business Studies, Vol. 46, No. 1, pp.63-86.

Ben Hamida, L. (2007) Inward Foreign Direct Investment and Intra-industry Spillovers: The Swiss Case, PhD Thesis, University of Fribourg, Switzerland.

Ben Hamida, L. (2011) 'FDI and spillovers in the Swiss services/construction industry: interaction effects between spillover mechanisms and domestic technological characteristics', Critical Perspectives on International Business, Vol. 7, No. 3, pp.224-249.

Ben Hamida, L. and Khairallah, R. (2014) 'Are there productivity spillovers from southern MNCs in Europe: evidence from Swiss service/construction industry?', Paper presented at EIBA Conference, December 2014, Uppsala, Sweden.

Ben Hamida, L. and Piscitello, L. (2009) 'Are foreign and domestic R\&D activities complements? Evidence from Swiss manufacturing firms', Paper presented at EIBA Conference, Reshaping the Boundaries of the Firm in an Era of Global Interdependence, 13-15 December 2009, Valencia.

Ben Hamida, L. and Piscitello, L. (2010) 'The impact of foreign R\&D activities on the MNC's performance at home: evidence from the case of Swiss manufacturing firms', Revue $d$ économie industrielle, Vol. 143, No. 143, pp.11-33.

Borensztein, E., De Gregorio, J. and Lee, J-W. (1998) 'How does foreign direct investment affect economic growth?', Journal of International Economics, Vol. 45, No. 1, pp.115-135.

Buckley, P.J., Clegg, J. and Wang, C. (2007) 'The impact of foreign ownership, local ownership and industry characteristics on spillover benefits from foreign direct investment in China', International Business Review, Vol. 16, No. 2, pp.142-158.

Cantwell, J. (1989) Technological Innovation and Multinational Corporations, Basil Blackwell, Oxford.

Cantwell, J. (1999) Foreign Direct Investment and Technological Change, Volume I and II, Edward Elgar Publishing Limited, USA. 
Cantwell, J. and Piscitello, L. (2005) 'Recent location of foreign-owned research and development activities by large multinational corporations in the European regions: the role of spillovers and externalities', Regional Studies, Vol. 39, No. 1, pp.1-16.

Cantwell, J. and Smeets, R. (2013) 'FDI motives and host country productivity effects of US MNEs', in Filip, D.B. and Ysabel, N. (Eds.): Innovation and Creativity, Edward Elgar, Belgium.

Chen, V.Z., Li, J. and Shapiro, D.M. (2012) 'International reverse spillover effects on parent firms: evidences from emerging-market MNEs in developed markets', European Management Journal, Vol. 30, No. 3, pp.204-218.

Chung, W. (2001) 'Identifying technology transfer in foreign direct investment: influence of industry conditions and investing firm motives', Journal of International Business Studies, Vol. 32, No. 1, pp.211-229.

Cohen, W. and Levinthal, D. (1989) 'Innovation and learning: the two faces of R\&D', Economic Journal, Vol. 99, No. 397, pp.569-596.

Crespo, N., Proença, I. and Fontoura, M.P. (2008) FDI Spillovers at the Regional Level: Evidence from Portugal, Working Paper No. 05/08, Lisbon University Institute.

Deng, P. (2007) 'Investing for strategic resources and its rationale: the case of outward FDI from Chinese companies', Business Horizons, Vol. 50, No. 1, pp.71-81.

Driffield, N. (2004) 'Regional policy and spillovers from FDI in the UK', The Annuals of Regional Science, Vol. 38, No. 4, pp.579-594.

Driffield, N. and Love, J.H. (2006) 'Does the motivation for foreign direct investment affect productivity spillovers to domestic sectors', Applied Economics Quarterly, Vol. 52, No. 1, pp.3-27.

Driffield, N. and Love, J.H. (2007) 'Linking FDI motivation and host economy productivity effects: conceptual and empirical analysis', Journal of International Business Studies, Vol. 38, No. 3, pp.460-473.

Dunning, J.H. (1992) Multinational Enterprises and the Global Economy, Addison-Wesley Publishing Company, Wokingham, England.

Duport, M. (2014) 'Managerial innovation and reverse-transfers in MNCs: beginnings from circulatory resources and for responsive management?', Paper presented at conference, Knowledge Transfer and Cultural Diversity in MNCs, 1-2 July 2014, Neuchâtel, Switzerland.

Elia, S. and Santangelo, G. (2012) 'Home country knowledge base as driver of emerging firms' asset-seeking investments in advanced countries', Paper presented at the European International Business Academy (EIBA) Conference, 7-9 December 2012, Sussex.

Girma, S. (2003) Absorptive Capacity and Productivity Spillovers from FDI: A Threshold Regression Analysis, Working Paper No. 25/2003, European Economy Group, Spain.

Girma, S. and Wakelin, K. (2002) 'Are there regional spillovers from FDI in the UK', in Greenawy, D. et al. (Eds.): Trade, Investment, Migration and Labour Markets, Macmillan, Basingstoke.

Gorgoni, S., Giuliani, E., Günther, C. and Rabellotti, R. (2012) 'Emerging market MNEs investing in Europe: a typology of subsidiary global-local connections', Paper presented at EIBA Conference, Brighton.

Griliches, Z. (1998) 'The search for R\&D spillovers', in Griliches, Z. (Eds.): $R \& D$ and Productivity: The Econometric Evidence, pp.251-268, National Bureau of Economic Research, Cambridge, MA.

Ha, Y.J. and Giroud, A. (2015) 'Competence-creating subsidiaries and FDI technology spillovers', International Business Review, Vol. 24, No. 4, pp.605-614.

Hale, G. and Long, C. (2006) What Determines Technological Spillovers of Foreign Direct Investment: Evidence from China, Discussion Paper, No. 934, Yale University.

Halpern, L. and Muraközy, B. (2005) Does Distance Matter in Spillovers?, CEPR Discussion Paper No. 4857, London. 
Higón, D.A. and Vasilakos, N. (2011) 'Foreign direct investment spillovers: evidence from the British retail sector', The World Economy, Vol. 34, No. 4, pp.642-666.

Kokko, A. and Kravtsova, V. (2012) 'Regional characteristics and effects of inward FDI: the case of Ukraine', Organizations and Markets in Emerging Economies, Vol. 3, No. 6, pp.91-118.

Kuemmerle, W. (1997) 'Building effective R\&D capabilities abroad', Harvard Business Review, March to April, Vol. 75, No. 2, pp.61-70.

Lin, M. and Kwan, Y.K. (2014) FDI Spatial Spillovers in China, MPRA Paper No. 60754.

Liu, X. and Wie, Y. (2006) 'Productivity spillovers from R\&D, exports and FDI in China's manufacturing sector', Journal of International Business Studies, Vol. 37, No. 4, pp.544-557.

Makino, S., Lau, C. and Yeh, R. (2002) 'Asset-exploitation versus asset-seeking: implications for location choice of foreign direct investment from newly industrialized economies', Journal of International Business Studies, Vol. 33, No. 3, pp.403-421

Marin, A. and Sasidharan, S. (2010) 'Heterogeneous MNC subsidiaries and technological spillovers, explaining positive and negative effects in India', Research Policy, Vol. 39, No. 9, pp.1227-1241.

Mariotti, S., Mutinelli, M., Nicolini, M. and Piscitello, L. (2015) 'Productivity spillovers from foreign multinational enterprises to domestic manufacturing firms: to what extent does spatial proximity matter?', Regional Studies, Vol. 48, No. 10, pp.1639-1653.

Mariotti, S., Nicolini, M. and Piscitello, L. (2013) 'Vertical linkages between foreign MNEs in service sectors and local manufacturing firms', Structural Change and Economic Dynamics, Vol. 25, pp.133-145.

Mathews, S.A. (2006) 'Dragon multinationals: new players in the 21 st century globalization', Asia Pacific Journal of Management, Vol. 23, No. 1, pp.93-113.

Menghinello, S., De Propris, L. and Driffield, N. (2010) 'Industrial districts, inward foreign investment and regional development', Journal of Economic Geography, Vol. 10, No. 4, pp.539-558, Oxford University Press.

Meyer, K. and Sinani, E. (2005) Spillovers from Foreign Direct Investment: A Meta-Analysis, Working Paper, Department of Economics, University of Reading.

Michel, J. and Narula, R. (2009) Reverse Knowledge Transfer and its Implications for European Policy, UNU-MERIT Working Paper Series 035, United Nations University.

Milelli, C. and Hay, F. (2008) Chinese and Indian Firms' Entry into Europe: Characteristics, Impacts and Policy Implications, Working Paper No. 2008-35, Université Paris X-Nanterre.

Mody, A. (1989) 'Strategies for developing information industries', in Cooper, C. and Kaplinsky, R. (Eds.): Technology and Development in the Third Industrial Revolution, Frank Cass, London.

Narula, R. and Marin, A. (2003) FDI Spillovers, Absorptive Capacities and Human Capital Development: Evidence from Argentina, Working Paper, No. 2003-016, Netherlands.

OECD (2013) Crisis Squeezes Income and Puts Pressure on Inequality and Poverty, Paris.

Piscitello, L. and Rabbiosi, L. (2004) 'More inward FDI? Medium-term effects of foreign acquisitions on target company productivity', Applied Economics Quarterly, Vol. 1, No. 1, pp.21-40.

Robinson, P. and Schweizer, M. (2006) Swiss Attractiveness Survey: What Foreign Companies Say, Ernest\&Young Ltd, Zurich.

Rui, H. and Yip, G. (2008) 'Foreign acquisitions by Chinese firms: a strategic intent perspective', Journal of World Business, Vol. 43, No. 2, pp.213-226.

Sauvant, K.P., Maschek, W.A. and McAllister, G. (2009) 'Foreign direct investment by emerging market multinational enterprises, the impact of the financial crisis and recession and challenges ahead', OECD Global Forum on International Investment, pp.7-8.

Silverberg, G. and Verspagen, B. (1994) 'Collective learning, innovation and growth in a boundedly rational, evolutionary world', Journal of Evolutionary Economics, Vol. 4, No. 3, pp.207-226. 
Sjöholm, F. (1999) 'Productivity growth in Indonesia: the role of regional characteristics and direct foreign investment', Economic Development and Culture Change, Vol. 47, No. 3, pp.559-584.

Svejnar, J., Gorodnichenko, Y. and Terrell, K. (2007) When Does FDI Have Positive to What Extent Does Spatial Proximity Matter?, IZA DP No. 3079.

UNCTAD (2011) Non-Equity Modes of International Production and Development, World Investment Report, New York and Geneva.

UNCTAD (2013) When Does FDI Have Positive Spillovers? Evidence from 17 Emerging Market Economies, World Investment Report Global, New York and Geneva.

UNCTAD (2014) Investing in the SDGs: an Action Plan, World Investment Report, New York and Geneva.

Wang, Y., Ning, L., Li, J. and Prevezer, M. (2014) 'Foreign direct investment spillovers and the geography of innovation in Chinese regions: the role of regional industrial specialization and diversity', Regional Studies.

World Bank (2011) Changes in Country Classifications, Posted on 07.01.2011 [online] http://data.worldbank.org/news/2010-GNI-income-classifications (accessed 26 January 2015).

$\mathrm{Xu}, \mathrm{X}$. and Sheng, Y. (2012) 'Are FDI spillovers regional? Firm-level evidence from China', Journal of Asian Economics, Vol. 23, No. 3, pp.244-258.

Yildizoglu, M. and Jonard, N. (1999) Sources of Technological Diversity, Cahiers de l'Innovation du CNRS, n 99030.

Zhan, J.X. (1995) 'Transnationalization and outward investment: the case of Chinese firms', Transnational Corporations, Vol. 4, No. 3, pp.67-100.

\section{Notes}

1 Southern economies used for empirical analysis of this study are China, Egypt, India, Israel, Latvia, Lebanon, Taiwan, and Ukraine. Southern economies include countries with low and middle income (transition and developing countries) based on the classification of the World Bank in 2011. Latvia has changed in July 2011 from high income to upper middle income country (World Bank, 2011). Israel registered in 2010 the highest relative income poverty rate in developed countries (OECD, 2013). This is the reason why it appears among these economies.

2 It is argued that foreign direct investment of southern MNCs in Europe is in services (Sauvant et al., 2009).

3 Our study tries to bridge the gap by testing spillovers for services/construction industry since a small number of studies have analysed spillovers in the service industry (namely, Hale and Long, 2006; Svejnar et al., 2007; Mariotti et al., 2013, 2015).

4 Kokko and Kravtsova (2012) highlighted the need to take into account regional differences when analysing the impact of inward FDI on the local economy. Girma and Wakelin (2002) indicate in addition that more-developed regions gain more from spillovers than others.

5 It is argued that home country characteristics determine FDI motivation of foreign affiliates (Buckley et al., 2007).

6 We use the regional classification of the KOF institute.

7 We use seven regional dummies.

8 MNC literature distinguishes two groups concerning spillovers: the effect of increased competition following the entry and/or presence of foreign affiliates and the effect of knowledge spillovers. The former operate through either a more productive use of existing technologies and resources or an assimilation of foreign technologies (competition-related spillovers). The latter may result from demonstrating new foreign knowledge and/or trained local workers who later work for local firms (demonstration and worker mobility-related spillovers). 
9 It is worth noting that in some cases a higher mark-up may be due to industry specificities (Narula and Marin, 2003).

10 We argue that, in the case of southern economies, RDI would not be a good measurement of FDI motivation since the RDI of these economies is often lower than that of developed countries, which imply that southern MNCs are naturally knowledge seekers when investing in developed countries.

11 'K-motiv' is based on the question number 9.1 of the questionnaire, which clearly asks the firm about the importance it shows in external knowledge sources in Switzerland that could influence its innovation capacity. Different knowledge sources are listed in the survey.

12 Based on 'K-motiv', all knowledge sources have been used to calculate the average five-point scale in order to classify southern firms according to their FDI motivations. However, various robustness tests have been performed using different mean values and with only knowledge sources considered important by southern firms for their innovation capacities. The classification results remain constant.

13 Questionnaire can be downloaded from http://www.kof.ethz.ch (Industrieökonomik), however, the firm-level data is unpublished and highly confidential.

14 The weights used to correct for the selection bias resulting from 'unit' non-response and for the deviations of the sample structure from that of the underlying population.

15 Switzerland has achieved competitive technological levels in many service industries such as; insurance and banking (Robinson and Schweizer, 2006).

16 We tested regression 5.2 and 5.5 using the share of highly qualified workers as a measurement of human capital. Our finding holds true, in which only FDI with KE motive induces positive knowledge diffusion and regional spillover benefits.

\section{Appendix}

\section{The model}

Equation (1) is derived from a Cobb-Douglas production function with value-added $\mathrm{Y}$ a function of two inputs, capital and labour,

$$
Y_{i, j, t}=A_{i, j, t} L_{i, j, t}^{\alpha_{1}} K_{i, j, t}^{\alpha_{2}}
$$

The level of productivity is given by $A_{i, j, t}$ which is assumed to vary across firms within each sector $j$ and across time $t$.

After taking logarithms of the variables to get equation (A1) into a linear form and adding a stochastic disturbance term $u_{i, j, t}$ to account for variations in the productive capabilities of the $i^{\text {th }}$ firm, we can rewrite equation (A1) for $t=2010$

$$
\operatorname{Ln} Y_{i, j, t}=a_{i, j, t}+\alpha_{1} \operatorname{Ln} L_{i, j, t}+\alpha_{2} \operatorname{Ln} K_{i, j, t}+u_{i, j, t} ; \quad\left(a_{i, j, t}=\operatorname{Ln} A_{i, j, t}\right)
$$

The hypothesis that productivity is affected by the shares of foreign presence in the region and outside the region, their interactions with human capital of the $i^{\text {th }}$ firm, and the level of industry competition, is tested as;

$$
\begin{aligned}
a_{i, j, t}= & \alpha_{3} F P_{j, r, t}+\alpha_{4} F P_{j, R-r, t}+\alpha_{5} H C_{i, j, t} \\
& +\alpha_{6} F P_{j, r, t} * H C_{i, j, t}+\alpha_{7} F P_{j, R-r, t} * H C_{i, j, t} \\
& +\alpha_{8} \text { Comp }_{i, j, t}+\alpha_{9} \text { Industry }_{j}+\alpha_{10} \text { Region }_{r}+\varepsilon_{i, j, r}
\end{aligned}
$$

Finally, combining equations (A2) and (A3) yields equation (1). 